\title{
Etnobiologi Kota Amlapura, Karangasem, Bali: Amla, Amlapura dan Phyllanthus emblica L. (Phyllanthaceae)
}

\author{
Ary Prihardhyanto Keim \\ Kelompok Penelitian Etnobiologi, Pusat Penelitian Biologi, \\ Lembaga Ilmu Pengetahuan Indonesia \\ Tukul Rameyo Adi \\ Muhamad Nikmatullah \\ Nissa Arifa \\ Fauzi Akbar \\ Kementerian Koordinator Bidang Kemaritiman dan Investasi, \\ Jakarta \\ Kelompok Penelitian Etnobiologi, Pusat Penelitian Biologi, \\ Lembaga Ilmu Pengetahuan Indonesia \\ Kelompok Penelitian Etnobiologi, Pusat Penelitian Biologi, \\ Lembaga Ilmu Pengetahuan Indonesia \\ Kementerian Koordinator Bidang Kemaritiman dan Investasi, \\ Jakarta \\ Wawan Sujarwo \\ Kelompok Penelitian Etnobiologi, Pusat Penelitian Biologi, \\ Lembaga Ilmu Pengetahuan Indonesia
}

Corresponding email

arypkeim@yahoo.com

\begin{abstract}
Amlapura is a Sanskrit name for the city of Karangasem and the result of the ethnobiological research conducted in this study indicates that it refers to a species of plant named Phyllanthus emblica (Phyllantaceae). In Indonesian, particularly Javanese the name is known as 'malaka', 'mlaka', 'kemloko', or 'mloko'. This present ethnobiological study also raises a possibility that the name 'mlaka' is an indigenous Austronesian word instead and entered Sanskrit through Dravidian languages.
\end{abstract}

Keywords: Amla, Amlapura, Bali, Karangasem, Phyllanthus, Phyllantaceae

\section{PENDAHULUAN}

Kabupaten Karangasem adalah salah satu dari delapan Kabupaten dan satu Kotamadya di Propinsi Bali yang terletak paling timur dari Pulau Bali. Kemudian di kabupaten ini terdapat Pura terbesar di Bali, yaitu Pura Besakih. Keberadaan Pura Besakih tidak lepas dari sejarah Karangasem sendiri yang tidak dapat dipisahkan dari Kerajaan Karangasem yang pernah dalam masanya menjadi kerajaan paling kaya dan makmur di Pulau Bali.

Kerajaan Karangasem (1600-1894) adalah sebuah kerajaan Hindu di Pulau Bali yang berdiri di abad ke-17 M dan berakhir menjelang akhir abad ke-19 M (Pringle, 2004; Agung, 2009). Di masa kejayaannya wilayah Kerajaan Karangasem bahkan meliputi seluruh Pulau Lombok yang ditaklukan pada tahun 1839 (Gin, 2004; Pringle, 2004). Kemakmuran yang dimiliki Kerajaan Karangasem bahkan membuatnya mampu membangun Pura sedemikian besar dan indah, Pura Besakih. 
Kerajaan Karangasem pernah mencapai kemakmurannya melalui perdagangan, antara lain komoditas pertanian (beras, Oryza sativa), perkebunan (kelapa, Cocos nucifera), kehutanan (kayu manis, Cinnamomum burmannii), dan pertambangan, terutama emas yang menarik para pedagang dari Nusantara dan manca negara, terutama China dan Arab datang. Diceritakan bahwa Amlapura, ibukota Kerajaan, sangat makmur dan kosmopolitan dengan para pedagang dari banyak wilayah Nusantara, Cina bahkan juga Arab dan Persia (Suparman, 1994). Sayangnya kemakmuran Kerajaan Karangasem juga mengundang kehadiran kolonial Belanda ke ujung paling timur Pulau Bali ini dan setelah melalui peperangan yang brutal dan licik, Belanda akhirnya menguasai Kerajaan Karangasem pada tahun 1894 (Suparman, 1994; Farram, 1997; Pringle, 2004).

Setelah kemerdekaan Indonesia, Karangasem ditetapkan menjadi salah satu Kabupaten di wilayah Propinsi Bali dengan tetap memilih Amlapura sebagai ibukota Kabupaten. Pada tahun 2015, Pemerintah Daerah Kabupaten Karangasem menetapkan Amlapura menjadi ibukota semenjak 22 Juni 1640, dan semenjak itu tanggal 22 Juni ditetapkan sebagai Hari Jadi Kota Amlapura dan dirayakan setiap tahun.

Sebagai sebuah kerajaan yang sangat makmur, Karangasem juga banyak menyimpan benda-benda pusaka kerajaan yang luar biasa indah dan bernilai budaya tinggi. Dalam kaitan tersebut, Amlapura (sekaligus Kabupaten Karangasem) juga menjadi anggota dari Jaringan Kota Pusaka Indonesia (JKPI), sebuah jaringan nirlaba antarkota di Indonesia yang saat ini beranggotakan 33 kota di seluruh Indonesia. Jaringan ini didirikan dengan tujuan menjaga kelestarian benda cagar budaya (BCB) peninggalan sejarah di Indonesia. Selain itu, Jaringan Kota Pusaka Indonesia sangat penting dalam upaya sosialisasi peraturan perundang-undangan tentang perlindungan benda cagar budaya (BCB). Oleh karena itu, penelitian ini bertujuan untuk Mengkaji kota Amlapura secara khusus dan Kabupaten Karangasem secara umum dari sudut ethnobiologi dalam kaitannya dengan tumbuhan Phyllantus emblica (Phyllantaceae).

\section{METODE}

Metode yang dipakai ialah eksplorasi dan keikutsertaan (partisipasi responden) langsung dengan wawancara secara terbuka dua arah (Martin, 1995; Cunningham, 2001; Bernard, 2006; Nolan dkk., 2011; Albuquerque dkk., 2014). Kabupaten Karangasem mencakup wilayah seluas $839,54 \mathrm{Km}^{2}$, di dalamnya termasuk gunung tertinggi di Pulau Bali, Gunung Agung dengan ketinggian $3031 \mathrm{~m}$ dpl. Kota Amlapura, ibukota Kabupaten Karangasem sendiri berjarak sekitar 79,1 km dari Bandar Udara Internasional Ngurah Rai (yang berlokasi di Kabupaten Badung) ke arah Timur Laut (Gambar 1) yang dapat ditempuh dengan kendaraan bermotor selama kurang lebih 2 jam (dalam kondisi normal).

\section{HASIL DAN PEMBAHASAN}

Salah satu keunikan masyarakat di Karangasem adalah toleransi beragama yang luarbiasa, khususnya antara Hindu dan Islam yang tertuang dalam sejarah lisan Desa Budakeling Bebandem, Karangasem yang melukiskan interaksi Hindu dan Islam pada sekitar akhir Kerajaan Majapahit dalam bentuk pesan-pesan dan petuah-petuah lisan yang masih hidup dan diterapkan di masyarakat Karangasem hingga hari ini (Sumarja, 2016; Maknun, 2018). Ini terwujud dalam salah satu bentuk kesenian Islami Marawis masyarakat Muslim 
asli Karangasem dari Banjar Muslim Kecicang, Desa Bungaya Kangin, Kecamatan Bebandem (Gambar 2).

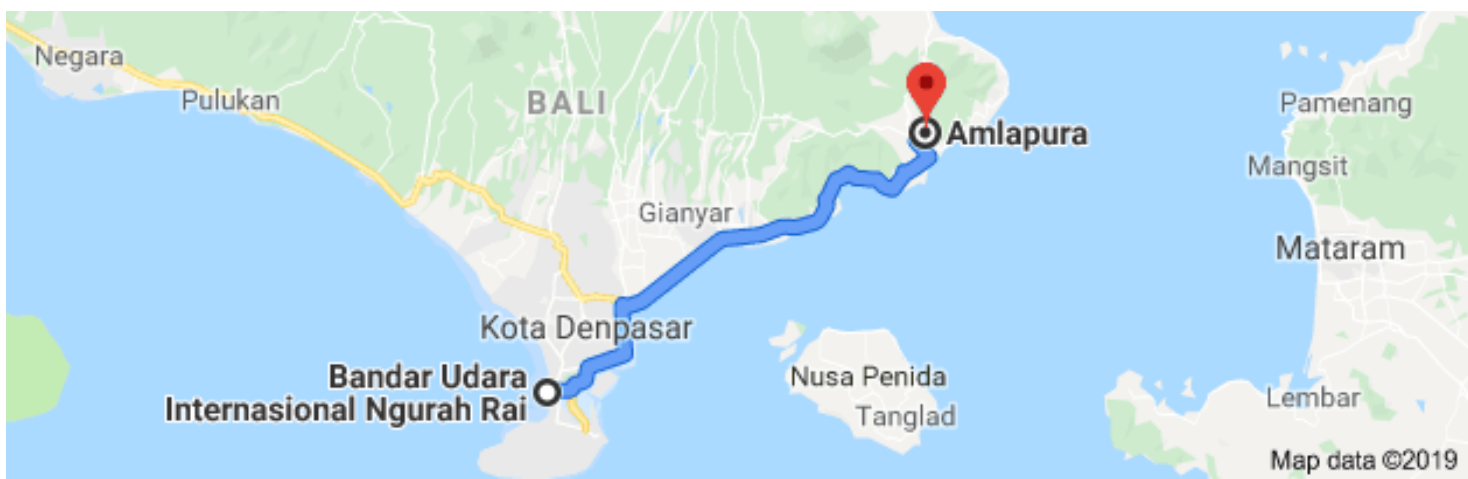

Gambar 1. Rute perjalanan dari Bandar Udara Internasional Ngurah Rai ke Kota Amlapura,

Kabupaten Karangasem [Google Map, 2019]

Secara historis kehadiran masyarakat Muslim di Karangasem adalah semenjak Raja Karangasem yang ke-empat yaitu Anak Agung Anglurah Ketut Karangasem berhasil menaklukan Pulau Lombok untuk pertama kalinya pada tahun 1692 yang kemudian diikuti kebijakan membawa orang Muslim yang berasal dari Lombok ke Kerajaan Karangasem menjadi cikal bakal masuknya Islam ke Karangasem (Sumarja, 2016). Umat muslim tersebut kemudian membentuk perkampungan yang kemudian dikenal dengan Kampung Kecicang Islam.

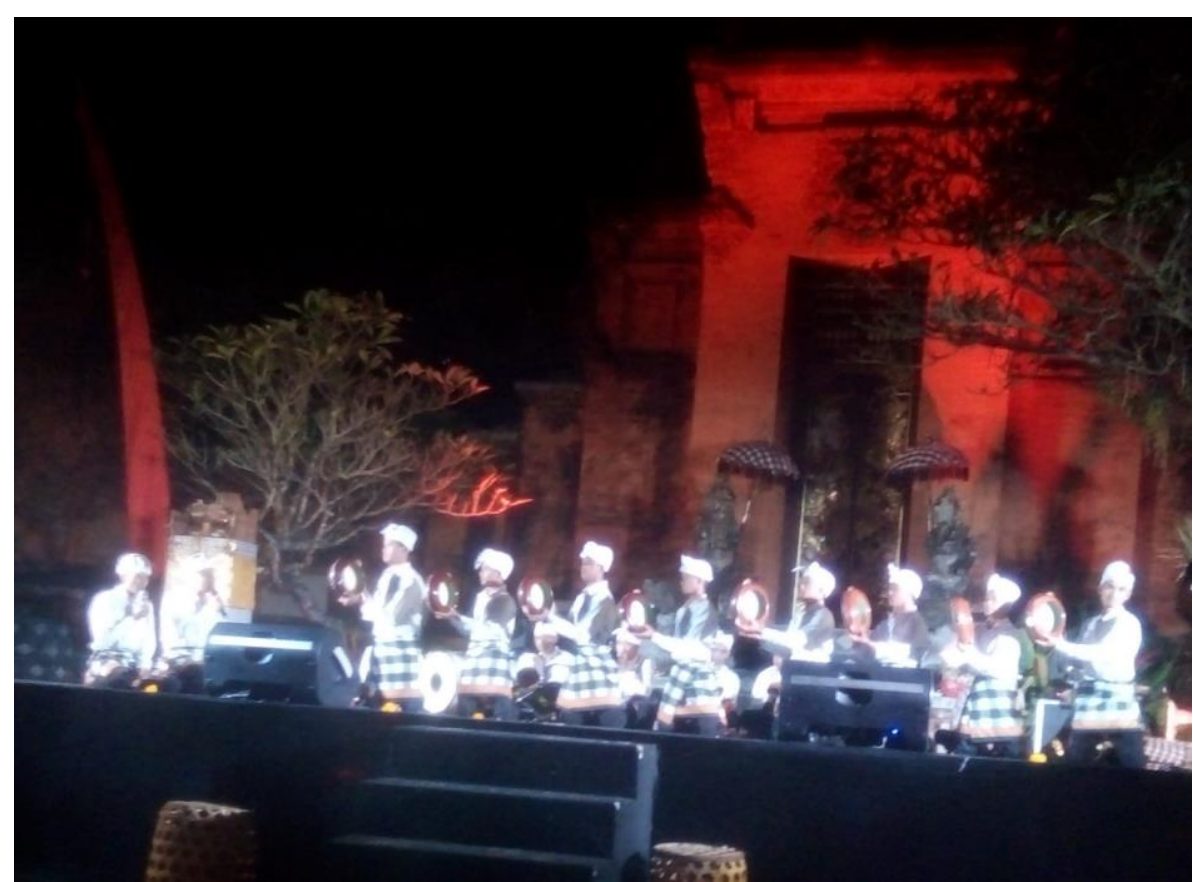

Gambar 2. Kesenian Marawis dari Banjar Muslim Kecicang, Desa Bungaya Kangin, Kecamatan Bebandem, Kabupaten Karangasem 
Kajian Etnobiologi terkait Kota Amlapura menuturkan sejarah kota itu sendiri terkait dengan jenis tumbuhan tertentu yang berujung kepada dua hipotesis.

\section{(1) Hipotesis Pertama}

Amlapura sebagai ibukota Kerajaan Karangasem yang kemudian juga dilanjutkan di era Kabupaten Karangasem telah lama dikenal setidaknya semenjak 22 Juni 1640. Meski begitu, tidak banyak orang yang tahu darimana kata "Amlapura" itu berasal, bahkan masyarakat Karangasem sendiri. Untuk kurun waktu yang panjang kata "Amlapura" menjadi misteri yang sepertinya tidak akan terpecahkan. Melalui pendekatan Etnobiologi di sini diduga kuat asal kata "Amlapura" berkaitan dengan vegetasi di Karangasem dan keyakinan yang kuat penduduknya akan Agama Hindu yang memang adalah agama mayoritas yang dianut masyarakat Karangasem bahkan hingga kini. Sebenarnya asal kata "Amlapura" yang merujuk kepada sejenis tumbuhan yang berbuah dengan rasa asam dan dalam Bahasa Sansekerta disebut "amla" sudah pernah diceritakan oleh salah seorang panglingsir atau tetua Puri Gede (Agung) Karangasem, Anak Agung Bagus Ngurah Agung. Namun tidak jelas identifikasi jenis tumbuhan yang dimaksud dengan "amla" itu.

Kajian Etnobiologi yang dilakukan dalam kegiatan ini sendiri selaras dengan yang dikatakan panglingsir atau tetua Puri Gede (Agung) Karangasem tersebut di atas dengan pijakan dasar kata "amla" itu sendiri. Kata "amla" jelas bukan kata asal bahasa-bahasa daerah Nusantara yang masuk ke dalam anak rumpun Bahasa Austronesia Barat-Tengah (West-Central Austronesians) yang mana bahasa-bahasa daerah di Pulau Bali juga termasuk ke dalamnya. Kata "amla" (atau lengkapnya "amalaka") diketahui berasal dari Bahasa Sansekerta dan artinya asam atau masam (Apte, 2017). Di dalam kitab Ayurveda sendiri kata "amla" merujuk kepada salah satu jenis tanaman yang digunakan dalam pengobatan masyarakat berperadaban Arya yang berbahasa Sansekerta, yaitu yang secara ilmiah disebut Phyllanthus emblica (Phyllanthaceae). Nama lain untuk tanaman ini antara lain "amala", "amalaka", "amalaki". Di dalam bahasa-bahasa asli Nusantara, khususnya Austronesia Barat-Tengah (West-Central Austronesians) jenis tanaman ini dikenal dengan nama-nama daerah "melaka", "mlaka", "mloko", "meloko" dan "balakka" (Khoiriyah dkk., 2015). Dalam Bahasa Indonesia standard nama tanaman ini adalah "Melaka". Phyllanthus emblica memiliki persebaran alami yang luas, mencakup Assam (India), Bangladesh, Borneo, Cina (bagian Tengah-Selatan dan Tenggara, termasuk Pulau Hainan), Himalaya (termasuk Nepal), India, Jawa, Kamboja, Laos, Semenanjung Malaya, Myanmar, Nusa Tenggara (termasuk Bali), Pakistan, Sri Lanka, Sumatera, Taiwan, Thailand, dan Vietnam (Balakrishnan dan Chakrabarty, 2007; Chakrabarty dan Balakrishnan, 2018). Ditambah beberapa wilayah di mana jenis ini diketahui dibudidaya, yaitu Pulau Andaman (India), Kuba, Mauritius, Puerto Rico, Trinidad-Tobago, dan Kepulauan Windward (Karibia) (Acevedo-Rodriguez dan Strong, 2007). Dengan kata lain, $P$. emblica adalah juga jenis alami di Indonesia, termasuk Pulau Bali. Lebih jauh lagi, $P$. emblica adalah juga jenis tumbuhan yang tumbuh alami dan asli Karangasem. Dari sudut pandang Etnobiologi, "amla" dan kaitannya dengan Amlapura di Karangasem menjadi sangat menarik. 


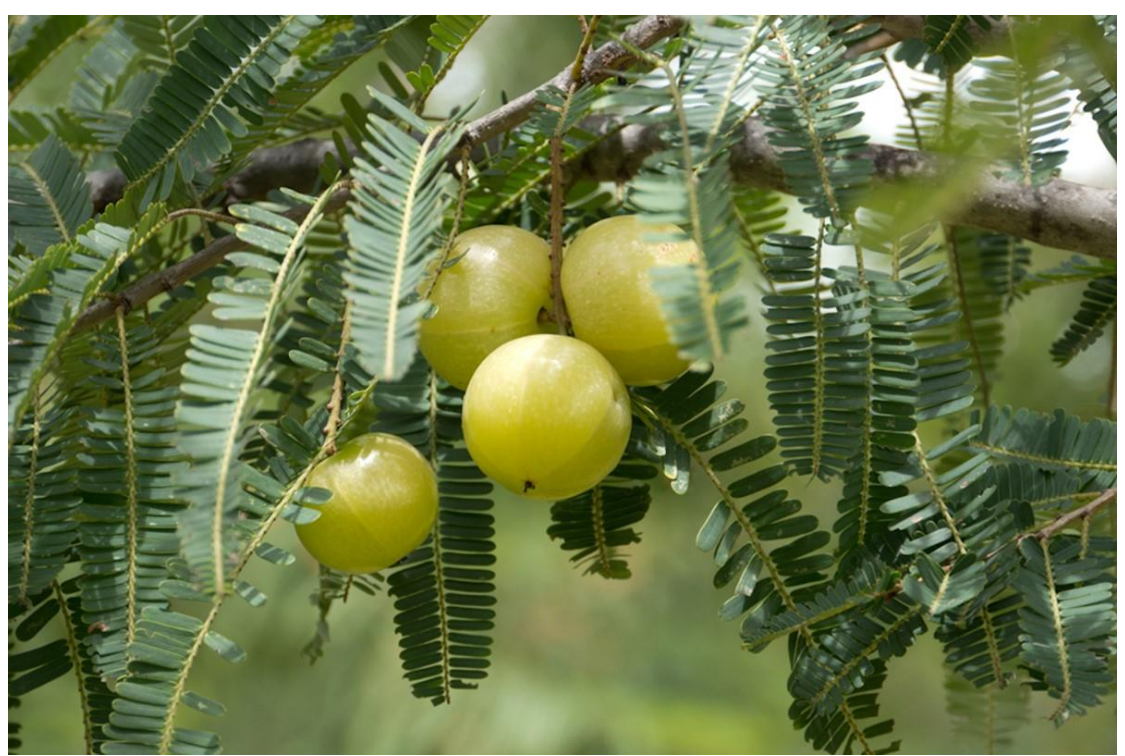

Gambar 3. "Amla" (Phyllanthus emblica; Phyllanthaceae)

[Sumber: efloraofindia]

Kata Amlapura adalah kata majemuk yang berasal dari dua kata dasar "amla" dan "pura". Kata "pura" sendiri dalam Bahasa Sansekerta berarti kota atau kota dengan benteng atau kota dengan istana di dalanya (Apte, 2017). Sehingga "Amlapura" berarti Kota Amla, kota yang banyak ditemukan tumbuhan "amla". Dengan kata lain, kota yang banyak ditemukan pohon "melaka" (Phyllanthus emblica). Ini merupakan penjelasan lebih lengkap dari apa yang diungkapkan sebelumnya oleh panglingsir Puri Gede (Agung) Karangasem sebelumnya di atas. Penjelasan tersebut juga secara langsung berkaitan dengan kata Karangasem itu sendiri. Kata "karang" dalam banyak bahasa daerah di Indonesia, seperti Bahasa Jawa, Sunda, dan Bali juga dapat bermakna kampung atau perkampungan atau dapat pula merujuk ke perkampungan luas dan lengkap atau kota. Dengan kata lain, "Karangasem" itu sendiri bermakna kampung yang banyak ditemukan tumbuhan dengan buah asam. Buah 'melaka' $(P$. emblica) sendiri masam rasanya mirip dengan kerabatnya satu marga, 'ceremai' atau 'cerme' ( $P$. acidus). Jadi, "Karangasem" tidak lain adalah nama Austronesia yang adalah padanan untuk nama Sansekerta "Amlapura" atau Karangasem adalah sama dengan Amlapura.

Penggunaan nama Sansekerta untuk menyebut nama "Karangasem" juga sebagai ibukota nampaknya berkaitan dengan agama yang mayoritas dianut masyarakat Karangasem sendiri, bahkan semenjak jaman Kerajaan Karangasem, yaitu Agama Hindu dengan bahasa ritual (keagamaan) yang dipakai tentu saja Sansekerta. Sehingga "Karangasem" pun diterjemahkan ke Bahasa Sansekerta menjadi "Amlapura". Ditambah lagi bahwa Phyllanthus emblica dianggap sebagai salah satu jenis tumbuhan yang disucikan dalam Agama Hindu di tanah airnya, India dan senantiasa dikaitkan dengan ritual penyembahan Dewa Wisnu dan Siwa (Bhatla dkk., 1984; Pandey dan Pandey, 2016).

Agama Hindu yang ada di Pulau Bali (i.e. Hindu Bali) sendiri merupakan sinkretisme kepercayaan Hindu aliran Saiwa, Waisnawa, dan Brahma dengan kepercayaan asli suku Bali (Gonda, 1975; Picard dan Madinier, 2011). Dengan sendirinya kedua dewa di atas, Wisnu dan Siwa, sangat dihormati di Bali. Terkait dengan itu, konsekuensinya tumbuhan 'amla' atau 'melaka' (Phyllanthus emblica) otomatis menjadi suci di Bali, khususnya Karangasem setidaknya sampai saat nama "Amlapura" ditetapkan. Meski begitu, nampak sekali bahwa peng-Sansekerta-an nama Karangasem menjadi Amlapura lebih kepada ide murni masyarakat 
Bali, khususnya Karangasem. Tidak ada kaitan dengan orang-orang India (baik Arya atau non-Arya seperti Tamil) bertutur Sansekerta sama sekali di Karangasem atau bahkan Pulau Bali. Hal ini ditandakan dengan ketiadaan kromosom Y-Arya atau Y-non-Arya di Bali dan -terutama sekali- tidak pernah ditemukannya sisa-sisa atau reruntuhan kapal karam dari India di Bali yang dapat dijadikan bukti adanya perniagaan lewat laut dari India ke Bali. Justru yang ada adalah bangkai kapal-kapal karam Austronesia (i.e. perahu bercadik; Gambar 6) di pantai-pantai selatan India beserta temuan DNA Austronesia (Vilar, 2015).

Temuan ini agaknya mengubah secara mendasar akan hubungan antara bangsa besar Austronesia (Nusantara) dan India di masa silam, di mana justru bangsa Austronesia lah yang berlayar dan berniaga ke India, bukan sebaliknya. Dengan kata lain, ide akan Hinduisme -termasuk konsep tumbuhan suci 'amla'- dibawa dan disebarkan sendiri oleh bangsa Austronesia ke Nusantara dari India. Bukti adanya kromosom Y dari India yang ditunjukkan Karafet dkk. (2005) perlu dipertimbangkan kembali.

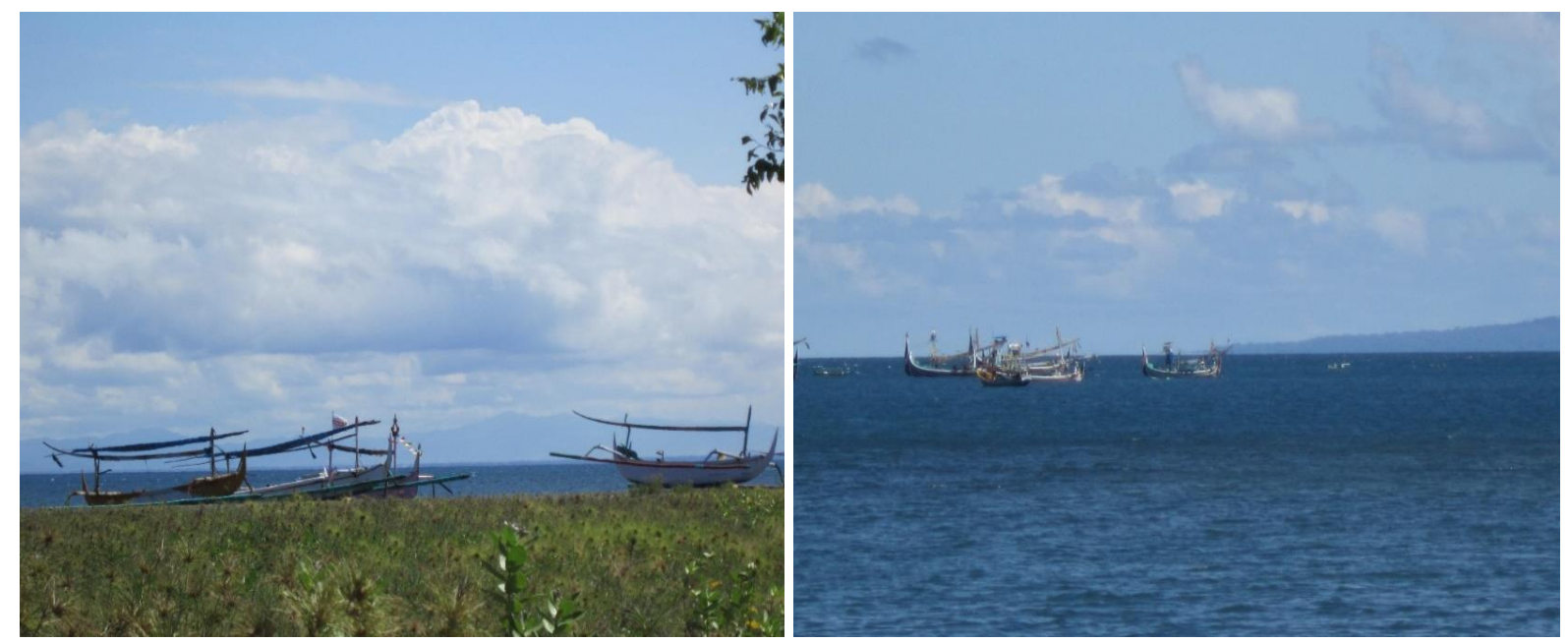

Gambar 4. Perahu bercadik di Bali Utara (kiri) yang biasa mengarungi selat Bali dari Pulau Bali ke Pulau Jawa pp. (kanan)

Kromosom Y tersebut (Karafet dkk., 2005) dapat ditafsirkan ulang sebagai terjadi perkawinan campur di India dan anak-anak hasil perkawinan campur tersebut dibawa pulang oleh ayah-ayah Austronesia mereka kembali ke Nusantara (termasuk Bali yang kaitan Hinduisme-nya kuat). Dengan kata lain, justru ada perkampungan (settlements) Bali di India, bukan sebaliknya. Meski begitu, ketiadaan kromosom Y tersebut di masyarakat Jawa dan Bali Aga menimbulkan kecurigaan bahwa itu relatif dari jaman yang lebih muda, setidaknya setelah pelarian masyarakat Hindu dari Majapahit (di akhir kejayaannya) ke Bali sekitar abad ke-16 Masehi hingga berdirinya kerajaan-kerajaan Hindu Majapahit di Bali yang berniaga sampai ke kerajaan-kerajaan Hindu di bagian selatan India yang dirasakan "bersahabat" dan "sekutu" sebagai sesama penganut Hindu. Jadi, sebenarnya keberadaan kromosom Y asal India di Bali adalah bukan dari masa perniagaan dan pelayaran maritim tua Austronesia yang legendaris.

\section{(2) Hipotesis Kedua}

Meski 'amla' disebut di Ayurveda, uniknya nama tersebut tidak dipakai untuk menyebut Phyllanthus emblica di tulisan ilmiah pertama jenis tersebut oleh orang Eropa, yaitu oleh Gubernur Jenderal Belanda di Koloni Malabar, India sekaligus juga naturalis, Hendrik Adriaan van Rheede tot Drakenstein di jilid pertama Hortus Malabaricus (Rheede 
tot Drakenstein, 1686; Gambar 5). Rheede tot Drakenstein melaporkan bahwa nama jenis tumbuhan tersebut dalam Bahasa Brahmani (i.e. Sansekerta) adalah 'Nelli-Camarum' (Gambar 6). Rheede tot Drakenstein menulis tentang uraian morfologi (penampilan) 'NelliCamarum' diikuti dengan kegunaannya dan gambar, tetapi tidak ada informasi kalau jenis tanaman ini disucikan oleh masyarakat Hindu. Gambar 'Nilli Camarum' sendiri sangat mirip dengan tampilan (perawakan) 'amla' atau 'melaka' (Phyllanthus emblica), termasuk tampilan daunnya yang sangat mirip dengan daun kelompok polong-polongan (legume) dan buah bulat dengan alur-alur di kulit luarnya (bandingkan Gambar 3 dengan Gambar 6). Di penelitian ini 'Nilli Camarum' dianggap sama dengan 'amla' atau 'melaka', jadi itu adalah Phyllanthus emblica. Rheede tot Drakenstein menggunkan nama 'Nilli Camarum' dapat dipahami di sini karena ia menerima nama itu dari penduduk asli Malabar di India yang bahasa ibunya adalah Bahasa Malayalam (Panikkar, 1900; Manilal, 1984; Drummond, 2010), di mana dalam Bahasa Malayalam Phyllanthus emblica disebut 'nelli' atau 'nellikka' (Gambar 7).
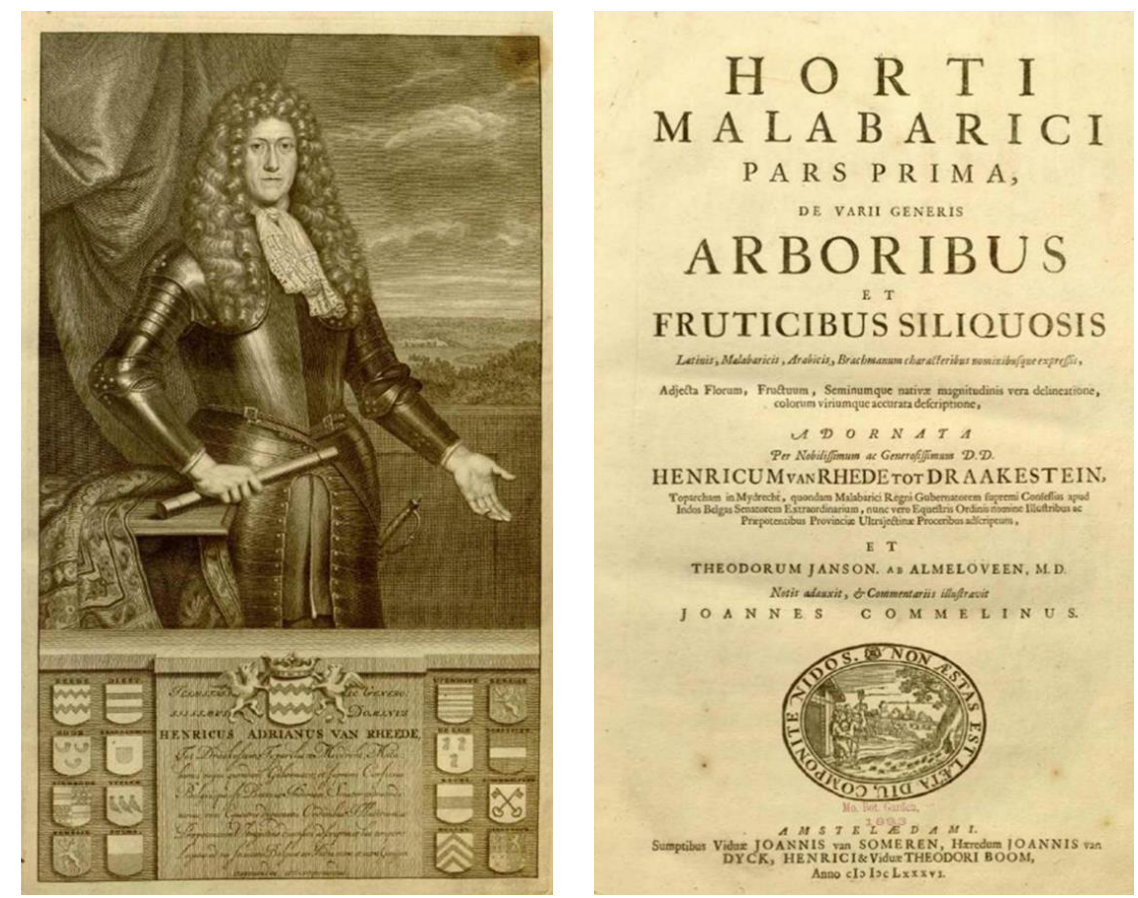

Gambar 5. Hendrik Adriaan van Rheede tot Drakenstein (kiri) dan halaman pertama Hortus Malabaricus tertanda tahun 1686 (kanan)

[Sumber: Rheede tot Drakenstein, 1686] 


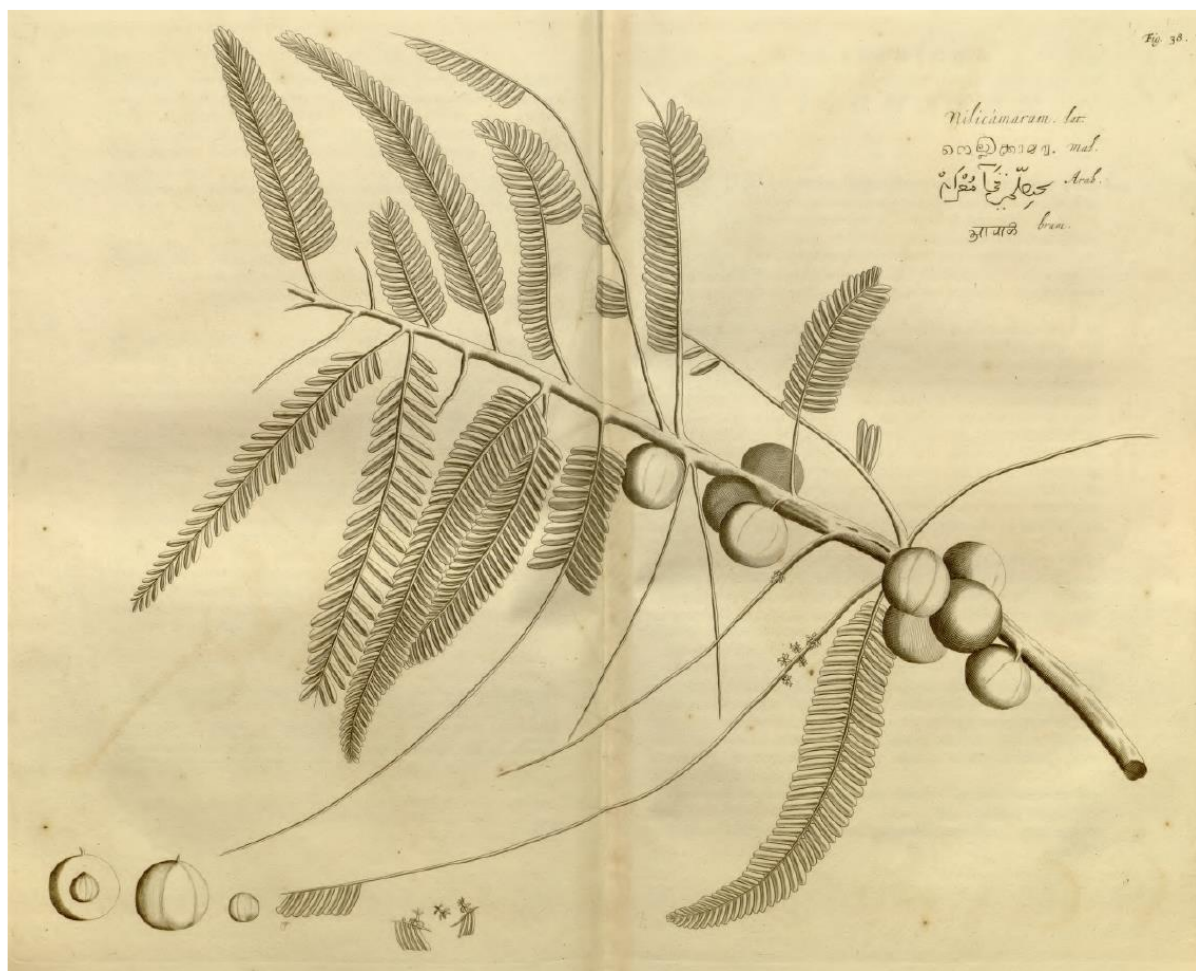

Gambar 6. Gambar 'Nilli Camarum' (Phyllanthus emblica) di Hortus Malabaricus [Sumber: Rheede tot Drakenstein, 1686]

• Assamese: আম্লখি amlaki • Bengali: আমলকী amlaki • Gujarati: આમળ। amla, આમલક amalak • Hindi: आमला amla, आंवला anwla, बहुमूली bahu-muli, ब्रह्मवृक्ष Brahma vriksh •

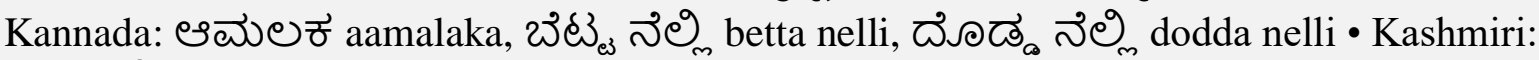
आमलकी amalaki, ओम्ल omala • Khasi: dieng sohmylleng • Konkani: आवळो avalo•

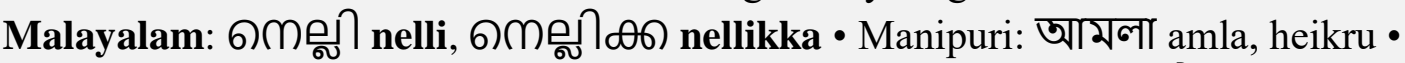
Marathi: अवळा avala, आंवळा aanvala • Mizo: sinhlu • Nepalese: अमलो amalo • Oriya: aula - Pali: आमलक amalak • Punjabi: भांटत्रा anwala, भाछ्ठित्डा aula • Sanskrit: अकर akara, अमलाः amalah, आमलक: amalakah, ब्रह्मवृक्ष Brahma vriksh, धात्रिका dhatrika, मण्डा manda, राधा radha, शंभुप्रिया shambhupriya, शिवा shiva, श्रीफली shriphali, सुधा sudha, तमका tamaka, तिष्या tishya, वज्रम् vajram, विलोमी vilomi • Tamil: ஆமலகி amalaki, அமிர்தபலம் amirta-palam, அத்தகோரம் attakoram, சிரோட்டம் cirottam, சிவை civai, இந்துளி intuli, கந்தாத்திரி kantattiri, காட்டுநெல்லி kattu-nelli, கோங்கம் konkam, கோரங்கம் korankam, நெல்லி nelli, தாத்திரி tattiri, தேசோமந்திரம் tecomantiram, தோப்புநெல்லி toppu-nelli, தோட்டி totti • Telugu: ఆమలకమ amalakamu, ధా[తి dhatri, నెల్లి nelli, ఉసిరి usiri • Urdu: آذ و anwla.

Gambar 7. Nama-nama daerah untuk Phyllanthus emblica dalam beberapa bahasa di India, yang dalam Bahasa Malayalam ditebalkan penulisannya

[Sumber: efloraofindia]

Gambar 7 juga memperlihatkan bahwa bahasa-bahasa di India yang menyebut $P$. emblica sebagai 'nelli' dengan segala varian pengucapan dan penamaannya adalah tergolong ke dalam keluarga bahasa-bahasa Dravida, bukan Sansekerta (lihat Iyengar, 1925). Jadi, di 
sini diyakini bahwa nama-nama yang berbunyi 'amla' atau 'amalaka' atau sebunyi dengan itu jelas bukan bahasa-bahasa Dravida dan nampaknya adalah kata-kata pinjaman dari Bahasa Sansekerta ke dalam bahasa-bahasa Dravida. Dengan kata lain, ini menimbulkan hipotesis bahwa nama asli untuk Phyllanthus emblica di India, khususnya India bagian selatan, di mana $P$. emblica banyak ditemukan tumbuh dan disebut dalam bahasa-bahasa Dravida sebagai 'nelli' atau nama-nama lain yang sebunyi dengannya (Gambar 7), bukan 'amla', 'amalaka', 'amalaki' atau nama-nama lain yang sebunyi dengannya.

Orang-orang berbahasa Dravida jauh lebih tua berada di daratan India daripada bangsa Arya yang bertutur bahasa Sansekerta (Iyengar, 1925; Kosambi, 1997; Thapar, 2002; Tripathi, 2006). Bahkan ada teori berbasis genetika dan biologi molekular (DNA) yang menduga bahwa orang-orang Dravida berasal dari kawasan Nubia di Afrika Timur dan bergerak ke daratan India sekitar 5000 tahun silam (Winters, 2008), jauh lebih tua dari turunnya orang-orang Arya Sansekerta dari Hindukush ke daratan India (Majumdar, 2015). Sebagai konsekuensi, setidaknya secara teori, orang-orang Dravida lebih dahulu mengenal Phyllanthus emblica daripada orang-orang Arya-Sansekerta. Jadi, orang-orang AryaSansekerta, setidaknya juga secara teori, tidak mengenal Phyllanthus emblica sampai mereka bersentuhan (kontak) dengan orang-orang Dravida,

Kajian DNA yang termasuk terkini di India membuktikan ada kontak antara orangorang Dravida di daratan India dengan pendatang dari sebelah timur yang berdasarkan kajian kromosom Y yang ada di tanah Dravida adalah bangsa Austronesia alias Nusantara (lihat Vilar, 2015). Dengan kata lain, bangsa yang berbahasa Dravida sudah kontak dengan pendatang bangsa berbahasa Austronesia jauh sebelum mereka kontak dengan bangsa AryaSansekerta. Karena Phyllanthus emblica juga jenis tumbuhan yang penyebaran alaminya sampai ke setidaknya bagian barat Austronesia seperti Semenanjung Malaya, Sumatera, Jawa, Kalimantan, dan Nusa Tenggara, termasuk Bali (Chakrabarty dan Balakrishnan, 2018), maka diyakini di sini bahwa masyarakat Austronesia sudah lebih dahulu mengenal jenis tanaman ini dari masyarakat Arya-Sansekerta. Sebagai konsekuensi, setidaknya secara teori, bangsa Austronesia sudah lebih dahulu mengenal nama yang merujuk kepada Phyllanthus emblica daripada bangsa Arya-Sansekerta. Bahkan bila merujuk kepada Winters (2008), di mana para leluhur Dravida baru bergerak dari Nubia di Afrika Timur menuju India sementara leluhur Austronesia sudah berada di Sundaland setidaknya pada jaman pleistocene akhir (membentang dari 126.000 hingga 5000 tahun silam; lihat Matsumura dkk., 2018) atau setidaknya 65.000-50.000 tahun silam (Oppenheimer dan Richards, 2001; Jones, 2007; Thomas, 2011), maka bangsa Austronesia seharusnya sudah mengenal Phyllanthus emblica sebelum bangsa Dravida. Diduga di sini bahwa nama dalam Bahasa Austronesia untuk Phyllanthus emblica adalah 'malaka' atau 'mlaka'. Karena kontak antara bangsa Austronesia dengan bangsa Dravida lebih dahulu daripada kontak antara bangsa Dravida dan AryaSansekerta merujuk kepada kajian DNA (Vilar, 2015), maka kata 'malaka' atau 'mlaka' masuk ke kosa kata bahasa Dravida sebelum kedatangan bangsa Arya-Sansekerta. Jadi, yang lebih mungkin adalah kata 'malaka' atau 'mlaka' masuk ke dalam Bahasa Sansekerta via Bahasa Dravida.

Contoh untuk kejadian di atas misalnya untuk cengkeh (Syzygium aromaticum; Myrtaceae). Sebagaimana diketahui bahwa 'cengkeh' atau 'cengkih' adalah endemik Kepulauan Maluku, khususnya Ternate dan Tidore. Nama dalam Bahasa Ternate adalah 'Lawang' atau 'Bunga Lawang' atau variasi bunyi dari itu seperti 'bongolawan' (Rumphius, 1741; Rumphius, 2011). Dalam Bahasa Sansekerta 'cengkeh' adalah लवंग yang berbunyi 'Lavanga' yang adalah jelas pengucapan Bahasa Sansekerta untuk Lawang, nama asli dalam Bahasa Austronesia (khususnya Ternate dan Tidore) untuk 'cengkeh'. Dan karena secara 
botani 'cengkeh' (Syzygium aromaticum) adalah endemik Maluku, maka tidak mungkin nama 'Lawang' dalam Bahasa Ternate dan Tidore berasal dari Bahasa Sansekerta 'Lavanga'. Dengan kata lain, kata 'Lavanga' dalam Bahasa Sansekerta berasal dari kata 'Lawang' dalam Bahasa Ternate atau Tidore yang mungkin masuk ke Sansekerta via para pedagang Nusantara yang berniaga ke India, bukan sebaliknya. Merujuk kepada contoh di atas, kata 'amalaka' boleh jadi adalah salah satu variasi pengucapan Bahasa Sansekerta untuk 'malaka' dari Bahasa Austronesia yang merujuk kepada jenis tumbuhan Phyllanthus emblica tersebut. Kata 'amla' sendiri diduga di sini pun diturunkan dari 'amalaka', di mana kebetulan rasa buah Phyllanthus emblica sendiri memang masam. Di sini juga diyakini bahwa sebelum merasakan buah Phyllanthus emblica, bangsa Arya-Sansekerta belum pernah merasakan rasa yang sangat masam atau "kecut". Memang ada buah-buahan dari kawasan subtropika -kawasan darimana bangsa Arya berasal (Hindukush, kawasan di sekitar Afghanistan - Iran) - seperti 'delima' (Punica granatum; Lythraceae) misalnya, namun tidak benar-benar sangat masam (kecut) sebagaimana ada di jenis-jenis buah-buahan tropika seperti 'belimbing wuluh' (Averrhoa bilimbi; Oxalydaceae), 'asam Jawa' (Tamarindus indica; Fabaceae), 'asam kelubi' (Eleiodoxa conferta; Arecaceae/Palmae), 'asam kandis' (Garcinia xanthochymus; Clusiaceae), dan 'asam galugur' (Garcinia atroviridis; Clusiaceae).

Kedua hipotesis di atas sangat menarik dan membutuhkan kajian ilmiah lebih lanjut, bukan hanya karena kaitannya dengan sejarah Karangasem, namun juga sejarah bangsa besar Austronesia itu sendiri sebagai bagian dari penguatan literasi bangsa Austronesia, khususnya Indonesia sebagai bangsa maritim.

\section{KESIMPULAN}

Amlapura adalah nama dalam Bahasa Sanskerta untuk Karangasem dan semuanya terkait dengan jenis tumbuhan Phyllanthus emblica (Phyllanthaceae). Dalam Bahasa Indonesia jenis tanaman ini disebut 'malaka', 'mlaka', 'kemloko' atau 'mloko'. Kabupaten Karangasem dan Keraton Karangasem menyimpan banyak sejarah yang menarik, bukan hanya sejarah Kabupaten dan Keraton Karangasem itu sendiri, namun juga Bali dan Lombok.

\section{UCAPAN TERIMAKASIH}

Pertama, para penulis mengucapkan terimakasih yang sebesar-besarnya kepada Pemerintah Daerah Kabupaten Karangasem dan Yayasan Jaringan Kota Pusaka Indonesia (JKPI) yang telah mengundang kami ke Karangasem sehingga penelitian ini dapat dilakukan. Penghargaan juga dilayangkan ke Kementerian Koordinator bidang Kemaritiman yang telah memfasilitasi penulis untuk hadir dan melakukan riset di Karangasem.

\section{DAFTAR PUSTAKA}

Acevedo-Rodríguez, P., Strong, M.T. 2012. Catalogue of seed plants of the West Indies. Smithsonian Contributions to Botany 98: 1-1192.

Agung, A.G.P. 2009. Peralihan sistem birokrasi dari tradisional ke kolonial. Pustaka Pelajar, Yogyakarta. 
Albuquerque, U.P., Ramos, M.A., De Lucena, R.F.P., Alencar, N.L. 2014. Methods and techniques in ethnobotany and ethnoecology. In Albuquerque, U.P., Da Cunha, L.V.F.C., De Lucena, R.F.P., Alves, R.R.N. (eds.). 2014. Methods and techniques used to collect ethnobiological data. Elsevier, New York, 15-38 p.

Apte, V.S. 2017. The student's English-Sanskrit dictionary $18^{\text {th }}$ edition. Motilal Banartidass Publisher, Delhi.

Balakrishnan, N.P., Chakrabarty, T. 2007. The family Euphorbiaceae in India: A synopsis of its profile, taxonomy and bibliography. Bishen Singh Mahendra Pal Singh, Dehra Dun.

Bernard, H.R. 2006. Methods in anthropology $4^{\text {th }}$ edition. Alta Mira, Littlefield.

Bhatla, N., Mukherjee, T., Singh, G. 1984. Plants: Traditional worshipping. Indian Journal of History of Science 19(1): 37-42.

Chakrabarty, T., Balakrishnan, N.P. 2018. Indo-Burmese Phyllanthaceae: A Taxonomic Revision. Bishen Singh Mahendra Pal Singh, Dehra Dun.

Cunningham, A.B. 2001. Applied ethnobotany: People, wild plant use and conservation. WWF and Earthscan Publications, London.

Drummond, R. 2010. Grammar and the Malabar languages. Gale Ecco, London.

Farram, S. 1997. The Dutch conquest of Bali: 311 years of negotiations, broken promises and war for 34 years of direct rule. PhD Thesis, Northern Territory University, Darwin.

Gin, O.K. 2004. Southeast Asia: A historical encyclopedia from Angkor Wat to East Timor. ABC CLIO, Oxford.

Gonda, J. 1975. The Indian religions in Pre-Islamic Indonesia and their survival in Bali. Handbook of Oriental Studies, Section 3: Southeast Asia Religions Part 1, 1-54p.

Iyengar, S. 1925. Dravidian India Vol. 1. The India Printing Works, Madras.

Jones, D. 2007. Going global: How humans conquered the world. New Scientist 2627: 36-41.

Karafet, T.M., Lansing, J.S., Redd, A.J., Watkins, J.C., Surata, S.P.K., Arthawiguna, W.A., Mayer, L., Bamshad, M., Jorde, L.B., Hammer, M.F. 2005. Balinese Y-Chromosome perspective on the peopling of Indonesia: Genetic contributions from Pre-Neolithic hunter-gatherers, Austronesian Farmers and Indian traders. Human Biology 77(1): 93113.

Khoiriyah, U., Pasaribu, N., Hannum, S. 2015. Distribusi Phyllanthus emblica L. di Sumatera Utara bagian Selatan. Biosfera 32(2): 98-102.

Kosambi, D.D. 1997. The culture and civilization of Ancient India in historical outline. Vikas Publishing House, New Delhi.

Majumdar, R.C. 2015. The history and culture of the Indian people Volume 1. The Vedic Age, Bharatiya Vidya Bhawan, Mumbai.

Maknun, M.L. 2018. Harmoni Hindu-Muslim berbasis tradisi lisan sejarah Desa Saren Budakeling, Karangasem, Bali. Fikrah: Jurnal Ilmu Aqidah dan Studi Keagamaan 6(2): 341-366.

Manilal, K.S. 1984. Hortus Malabaricus and the ethnohistorical knowledge of Ancient Malabar. Ancient Science of Life 4(2): 96-99.

Martin, G. 1995. Ethnobotany: A method manual. Chapman and Hill, New York.

Matsumura, H., Shinoda, K.I., Simanjuntak, T., Oktaviana, A.A., Noerwidi, S., Sofian, H.O. 2018. Cranio-morphometric and aDNA corroboration of the Austronesian dispersal model in ancient Island Southeast Asia: Support from Gua Harimau, Indonesia. PLoS ONE 13(6): e0198689. 
Nolan, J.M., Turner, N.J. 2011. Ethnobotany: The study of people-plants relationships. $\underline{I n}$ Anderson, N.J., Pearsall, D., Hunn, E., Turner, N.J. (eds.). 2011. Ethnobiology. Willey-Blackwell, Hoboken, New Jersey, 133-148 p.

Oppenheimer, S., Richards, M. 2001. Fast trains, slow boats and the ancestry of the Polynesian islanders. Science Progress 84(3): 157-181.

Pandey, D., Pandey, V.C. 2016. Sacred plants from ancient to modern era: Traditional worshipping towards plants conservation. Tropical Plant Research 3(1): 136-141.

Panikkar, T.K. 1900. Malabar and its folk. G.A. Natesan and Co., Madras.

Picard, M., Madinier, R. 2011. The politics of religion in Indonesia: Syncretism, orthodoxy and religious contention in Java and Bali. Routledge, London.

Pringle, R. 2004. A short history of Bali: Indonesia's Hindu realm. Allen and Unwind, Crows Nest.

Rheede tot Drakenstein, H.A. 1686. Hortus Malabaricus. Johannes van Someren, Johannes van Dyck, Hendrijk and Theodore Boom Publication, Amsterdam.

Rumphius, G.E. 1741. Herbarium Amboinense Volume 2. Franciscus Changuion, Amsterdam.

Rumphius, G.E. 2011. The Ambonese herbal. Being a description of the most noteworthy trees, shrubs, herbs, land-and water-plants which are found in Amboina and the surrounding islands according to their shape, various names, cultivations and uses: Together with several insects and animals Volume 2. Translated by Beekman, E.M. 2011. Yale University Press, New Haven.

Sumarja, I.M. 2016. Sejarah masuknya Islam dan perkembangan pemukiman Islam di Desa Kecicang Kabupaten Karangasem Provinsi Bali. Kepel Press dan Balai Pelestarian Budaya Bali, Yogyakarta.

Suparman, L.G. 1994. Babad Sakra. Departemen Pendidikan dan Kebudayaan Republik Indonesia, Jakarta.

Thapar, R. 2002. Early India: From the origins to AD 1300. Penguin Books, London.

Thomas, D.R. 2011. Origins of the Austronesian peoples. In Rahman, N.H.S.A., Ramli, Z., Musa, M.Z., Jusoh, A. (eds.). 2001. Malay world: One contribution to knowledge. Institut Alam dan Budaya Melayu, University Kebangsaan Malaysia, Kuala Lumpur, 13-21 p.

Tripathi, R.S. 2006. History of ancient India. Motilal Banarsidass, New Delhi.

Vilar, M. 2015. DNA reveals unknown ancient migration into India. National Geographic. nationalgeographic.org

Winters, C. 2008. Origin and spread of Dravidian speakers. International Journal of Human Genetics. 8(4): 325-329 